Удк 631.816.1:633:15

(C) 2021

\title{
ВПЛИВ ТРИВАЛИХ
}

\section{АНТРОПОГЕННИХ НАВАНТАЖЕНЬ НА ФУНКЦІОНАЛЬНИЙ СТАН АГРОЕКОСИСТЕМ КУКУРУДЗИ}

\author{
О.Ф. Стасів ${ }^{1}$, Ю.М. Оліфір ${ }^{2}$, А.Й. Габриєль ${ }^{3}$, \\ T.B. Партика 4 , О.С. Гавришко \\ ${ }^{1}$ кандидат економічних наук \\ 2, 3, 5 кандидати сільськогосподарських наук

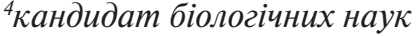

Інститут сільського господарства Карпатського регіону НААН

вул. Грушевського, 5, с. Оброшине Пустомитівського р-ну Львівської обл., 81115, Україна e-mail: 1inagrokarpat@gmail.com, ${ }^{2}$ olifir.yura@gmail.com, ${ }^{3}$ gabriel.annay@gmail.com, ${ }^{4}$ tetyana.partyka@gmail.com, ${ }^{5}$ havryshko0@gmail.com

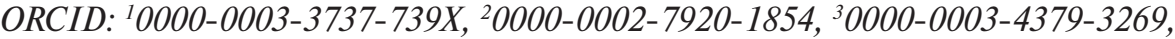
${ }^{4} 0000-0001-7912-5292,{ }^{5} 0000-0002-5458-0691$

Надійшла 17.03.2021

Мета. Дослідити в умовах стаціонарного досліду вплив тривалого застосування різних систем удобрення і періодичного вапнування на емісію $\mathrm{CO}_{2}$, інтенсивність окисно-відновних і біотичних процесів в агроценозах кукурудзи для ефективного управління родючістю ясно-сірих лісових поверхнево оглеєних грунтів. Методи. Польові дослідження - для вимірювання інтенсивності виділення $\mathrm{CO}_{2}$, рівня окисно-відновного потенціалу, протеолітичної та загальної біологічної активності ґрунту, фізико-хімічні - визначення $\mathrm{pH}_{\text {кс, }}$ порівняльно-аналітичні - для аналізу та обгрунтування одержаних результатів, математико-статистичні - для оцінки достовірності результатів досліджень. Результати. Із застосуванням на ясно-сірих лісових поверхнево оглеєних ґрунтах органо-мінеральної (10 т/га гною і $\left.\boldsymbol{N}_{65} \boldsymbol{P}_{68} K_{68}\right)$ та мінеральної $\left(N_{105} P_{101} K_{101}\right)$ систем удобрення на фоні вапнування дозою $\mathrm{CaCO}_{3}$, розрахованою за кислотно-основною буферністю $(2,5$ т/га), на 5-й рік післядії підвищується кислотність, що призводить до зростання інтенсивності виділення $\mathrm{CO}_{2}$, окисно-відновного потенціалу та зниження біотичної активності під час вегетації кукурудзи. Отримані результати свідчать про доцільність проведення чергового туру вапнування ясно-сірих лісових поверхнево оглеєних грунтів перед початком кожної з наступних 4-пільних ротацій оптимальною дозою $\mathrm{CaCO}_{3}$, розрахованою за рН-буферністю, що забезпечить поступове зрушення кислотно-основної рівноваги та екологічно безпечне і збалансоване використання кислих грунтів. Висновки. На основі отриманих результатів досліджень у тривалому стаціонарному досліді показано доцільність використання в системі агроекологічного моніторингу показників емісії $\mathrm{CO}_{2}$, окисно-відновного потенціалу та біотичної активності. Установлено, що запропоновані діагностичні характеристики разом з агрохімічними показниками дають можливість повною мірою оцінити вплив різних антропогенних навантажень на агроекосистему. 
Ключові слова: добрива, вапнування, кислотність, емісія $\mathrm{CO}_{2}$, окисно-відновний потенціал.

DOI: https://doi.org/10.31073/agrovisnyk202106-02

Проблема родючості ґрунтів $є$ однією 3 найактуальніших проблем у світовому масштабі. Ефективність сільськогосподарського використання ґрунтів безпосередньо залежить від даних екологічної ситуації та складу ґрунтового повітря. Тому для повнішого обстеження земель сільськогосподарського призначення з метою визначення їх якісних показників і подальшого застосування потрібно проводити комплексний моніторинг одночасно з вивченням найважливіших характеристик ґрунтів [1].

Меліорація $€$ важливим заходом пришвидшеного окультурення малопродуктивних ґрунтів. Однак хімічна меліорація, в основі якої лежить розрахунок доз вапна за гідролітичною кислотністю, призводить до розвитку небезпечних явищ, особливо на низькобуферних за кислотно-основною рівновагою ясно-сірих лісових поверхнево оглеєних ґрунтах. При цьому дуже часто спостерігаються підвищення мінералізації органічної речовини, інтенсифрікація вимивання нітратів, кальцію, водорозчинної органіки в підґрунтові води, зростання емісії діоксиду вуглецю та газоподібних сполук азоту, забруднення поверхневих і підґрунтових вод [2].

Кислі та гідроморфні ґрунти, які поширені переважно в західному регіоні України, характеризуються низькими потенціалом родючості та екологічною якістю. Через це вони $є$ особливо вразливими до інтенсивних антропогенних навантажень і стресів, пов'язаних із глобальними змінами клімату. Оскільки згідно з методологією [3] прогнозоване підвищення температури посилить дисоціацію органічних кислот у ґрунті, інтенсивність впливу ґрунтової біоти на мінералізацію органічної речовини і додаткове утворення діоксиду карбону. Тому нині особливого значення набувають методи оптимального управління основними функціями ґрунтів, які передбачають вибір і пошук найактивніших варіантів їх оптимізації, так звані інноваційні моделі управління елементами родючості [4].
Єдиним реальним і безальтернативним способом для мінімізації екологічних ризиків і загроз, що виникають на сучасному етапі аграрного виробництва, $є$ перехід на системне управління родючістю ґрунтів [5]. Такий підхід дає змогу здійснювати нормування антропогенних навантажень у режимі суворої гармонізації продуктивних фрункцій ґрунтів з екологічними [6].

Важливими діагностичними показниками, які дають можливість оцінити характеристику процесів у ґрунтовому середовищі, їх спрямованість та інтенсивність, є емісія діоксиду карбону ґрунтом, окисно-відновний потенціал (ОВП) і біотична активність.

Мета досліджень - в умовах стаціонарного досліду вивчити вплив тривалого застосування різних систем удобрення і періодичного вапнування на емісію $\mathrm{CO}_{2}$, інтенсивність окисно-відновних і біотичних процесів в агроценозах кукурудзи для ефективного управління родючістю ясно-сірих лісових поверхнево оглеєних ґрунтів.

Методика досліджень. Отримати об'єктивну оцінку впливу різних антропогенних факторів на умови функціонування та збалансоване використання кислих ґрунтів можна лише за умови режимних досліджень упродовж тривалого періоду спостережень в умовах стаціонарного досліду. Одним із таких є стаціонар відділу агрохімії та ґрунтознавства Інституту сільського господарства Карпатського регіону НАAН, закладений у 1965 р. та занесений у Реєстр довгострокових стаціонарних польових дослідів НАAН (атестат реєстрації НАAН № 29). Дослідження виконували в Х ротації сівозміни впродовж 2017-2019 рр.

Стаціонарний дослід розміщений на 3-х полях, кожне з яких налічує 18 варіантів у 3-разовому повторенні. Розташування варіантів одноярусне, послідовне. Загальна площа ділянки становить 168 м², обліко-

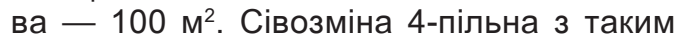
чергуванням культур: кукурудза на силос - ячмінь ярий із підсівом конюшини лучної - конюшина лучна — пшениця 
3ЕМЛЕРОБСТВО, ҐРУНТОЗНАВСТВО, АГРОХІМІЯ

озима. Агротехніка вирощування культур, обробіток ґрунту і догляд за посівами загальноприйняті для умов зони Лісостепу Західного.

Агрохімічна характеристика орного шару ясно-сірого лісового поверхнево оглеєного ґрунту до закладання досліду така: уміст гумусу (за Тюріним) - 1,42\%, $\mathrm{pH}_{\text {кс। }}-4,2$, гідролітична кислотність (за Каппеном) - 4,5, обмінна (за Соколовим) - 0,6 мг·екв./100 г ґрунту, уміст рухомого алюмінію - 60 мг/кг ґрунту, рухомого фосфрору (за Кірсановим) і обмінного калію (за Масловою) - відповідно 36 і 50 мг/кг ґрунту.

У досліді застосовували напівперепрілий гній великої рогатої худоби на солом'яній підстилці, аміачну селітру $(34,5 \%)$, гранульований суперфосфат $(19,5)$, калійну сіль (40), нітроамофоску (NPK по 16\%). За використання нітроамофоски вміст NPK збалансовували згідно з рівнями удобрення простими добривами. Гній (40-60 т/га) вносили під кукурудзу, фосфорно-калійні добрива застосовували восени, азотні під передпосівну культивацію. Вапнування згідно зі схемою досліду проводили перед початком IX ротації сівозміни, в якій також відкориговано дози внесення добрив під культури сівозміни. Як вапнякові матеріали використовували вапнякове борошно $\left(93,5 \% \mathrm{CaCO}_{3}\right)$. Із VIII ротації другий укіс конюшини лучної заорювали як органічне добриво в усіх варіантах досліду.

Дослідження емісії діоксиду карбону ясно-сірим лісовим поверхнево оглеєним ґрунтом, зміну ОВП та біотичної активності залежно від тривалого удобрення та періодичного вапнування проводили під час вегетації кукурудзи, якою розпочинається Х ротація сівозміни у фразах сходів, 5-6-ти листочків, молочно-воскової стиглості. Вимірювання $\mathrm{CO}_{2}$ здійснювали у варіантах: абсолютного контролю (без унесення добрив, варіант 1); органо-мінеральної системи удобрення (10 т/га сівозмінної площі гною $\left.+\mathrm{N}_{65} \mathrm{P}_{68} \mathrm{~K}_{68}\right)$ на фроні періодичного вапнування 1,0 н СаCO 3 за Нг (6,0 т/га вапнякового борошна, варіант 7) та аналогічної системи удобрення на фоні внесення оптимальної дози вапна, розрахованої за кислотно-основною буферністю (2,5 т/га, варіант 8); мінеральної системи
Вплив тривалих антропогенних навантажень на функціональний стан агроекосистем кукурудзи

удобрення $\left(\mathrm{N}_{105} \mathrm{P}_{101} \mathrm{~K}_{101}\right)$ на фроні вапнування $1,5 \mathrm{H} \mathrm{CaCO}_{3}$ за $\mathrm{Hг}(9,0$ т/га, варіант 17) і на фоні внесення $\mathrm{CaCO}_{3}$ за кислотно-основною буферністю (2,5 т/га, варіант 18) та мінеральної системи удобрення $\left(\mathrm{N}_{65} \mathrm{P}_{68} \mathrm{~K}_{68}\right.$, варіант 15).

Інтенсивність виділення діоксиду карбону з поверхні ґрунту визначали в польових умовах на 2-канальному інфрачервоному газовому аналізаторі $\mathrm{CO}_{2}$-метрі К-30 Probe та відповідному програмному забезпеченні (DAS 100). Вимірювання проводили камерно-статичним методом [7] у згаданих варіантах досліду впродовж вегетаційного періоду кукурудзи в зазначених фразах вегетації. У закритій камері-ізоляторі, заглибленій у ґрунт на глибину 0,05 м (об'ємом 5 л), концентрацію $\mathrm{CO}_{2}$ на поверхні ґрунту (площею 0,023 м²) вимірювали газоаналізатором протягом фріксованого часу (експозиції 30 хв) із розрахунком показників емісії діоксиду карбону 3-5 разів на день із визначенням середнього значення.

Окисно-відновний потенціал вимірювали в польових умовах за допомогою платинового і хлорсрібного електродів порівняння згідно з ДСТУ ISO 11271:2004.

Зразки ґрунту для визначення обмінної кислотності відбирали перед сівбою кукурудзи в досліджуваних варіантах з орного шару ясно-сірого лісового поверхнево оглеєного ґрунту (0-25 см) і готували до аналізів згідно з ДСТУ ISO 11464-2001. Визначення $\mathrm{pH}$ сольової витяжки здійснювали потенціометричним методом згідно з ДСТУ ISO 10390-2001, протеолітичну активність ґрунту визначали за розкладанням желатинового шару рентгенівської плівки, загальну - за розкладанням лляного полотна аплікаційним методом Мішустіна [8].

Математико-статистичну обробку результатів досліджень виконували дисперсійним методом із використанням програм Microsoft Excel i Statistica 6.0. Дані в таблицях представлені як середнє арифметичне

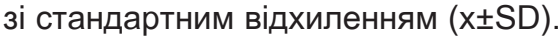

Результати досліджень. Динаміка виділення діоксиду вуглецю в полі кукурудзи мала свої особливості, зумовлені не лише впливом різних систем удобрення, а й тривалістю післядії доз унесення вапна, зокрема поступовим зниженням упродовж 
ЗЕМЛЕРОБСТВО, ҐРУНТОЗНАВСТВО, АГРОХІМІя
Вплив тривалих антропогенних навантажень на функціональний стан агроекосистем кукурудзи 4-х років попередньої ротації ефективності внесення 2,5 т норми $\mathrm{CaCO}_{3}$, розрахованої за кислотно-основною буферністю, порівняно з 6 і 9 т/га $\mathrm{CaCO}_{3}$, розрахованими за гідролітичною кислотністю (Нг). У полі кукурудзи - першої культури $\mathrm{X}$ ротації простежується пряма залежність між величиною кислотності $\left(\mathrm{pH}_{\text {ксІ }}\right)$ та інтенсивністю виділення $\mathrm{CO}_{2}$.

Під час сходів та у фразі 5-6-ти листочків інтенсивність виділення $\mathrm{CO}_{2}$ в полі кукурудзи була найвищою на контролі та у варіанті мінеральної системи удобрення і становила відповідно 13,3 і 6,0 та 9,7 і 5,6 рpm/хв при $\mathrm{pH}_{\mathrm{\kappa Cl}} 4,22$ і 4,03. За мінеральної системи удобрення на фроні вапнування $1,5 \mathrm{H} \mathrm{CaCO}_{3}$ за Нг інтенсивність виділення діоксиду вуглецю в цей період становила 7,8-12,2 ppm/хв проти 6,4-13,5 ppm/хв за аналогічної системи удобрення на фоні вапнування оптимальною дозою. У варіантах органо-мінеральної системи удобрення на фоні вапнування 1,0 н $\mathrm{CaCO}_{3}$ за Нг інтенсивність виділення $\mathrm{CO}_{2}$ становила 4,7-6,5 проти
6,5-7,7 ppm/хв в аналогічній системі удобрення на фоні вапнування дозою $\mathrm{CaCO}_{3}$, розрахованою за кислотно-основною буферністю. Зазначена залежність за варіантами залежно від дози внесення вапна зберігалася впродовж усього періоду росту і розвитку. Перед збиранням урожаю у варіантах органо-мінеральної та мінеральної систем удобрення на фоні відповідно 1,0 і 1,5 н $\mathrm{CaCO}_{3}$ за Нг інтенсивність виділення $\mathrm{CO}_{2}$ становила 11,9 і 9,3 ррm/хв при $\mathrm{pH}_{\text {ксl }}$ 5,18 і 5,53 проти 9,7 ppm/хв за мінеральної системи удобрення на фоні вапнування оптимальною дозою $\mathrm{CaCO}_{3}$ за кислотно-основною буфрерністю при $\mathrm{pH}_{\text {кс }}$ відповідно 4,82. Це свідчить про необхідність повторного вапнування (після 4-х років IX ротації) оптимальною дозою $\mathrm{CaCO}_{3}$, розрахованою за кислотно-основною буферністю перед початком наступної ротації (рис. 1).

Підвищення кислотності ґрунтового розчину в умовах ясно-сірого лісового поверхнево оглеєного ґрунту у варіантах контролю та мінерального удобрення підвищує рівень

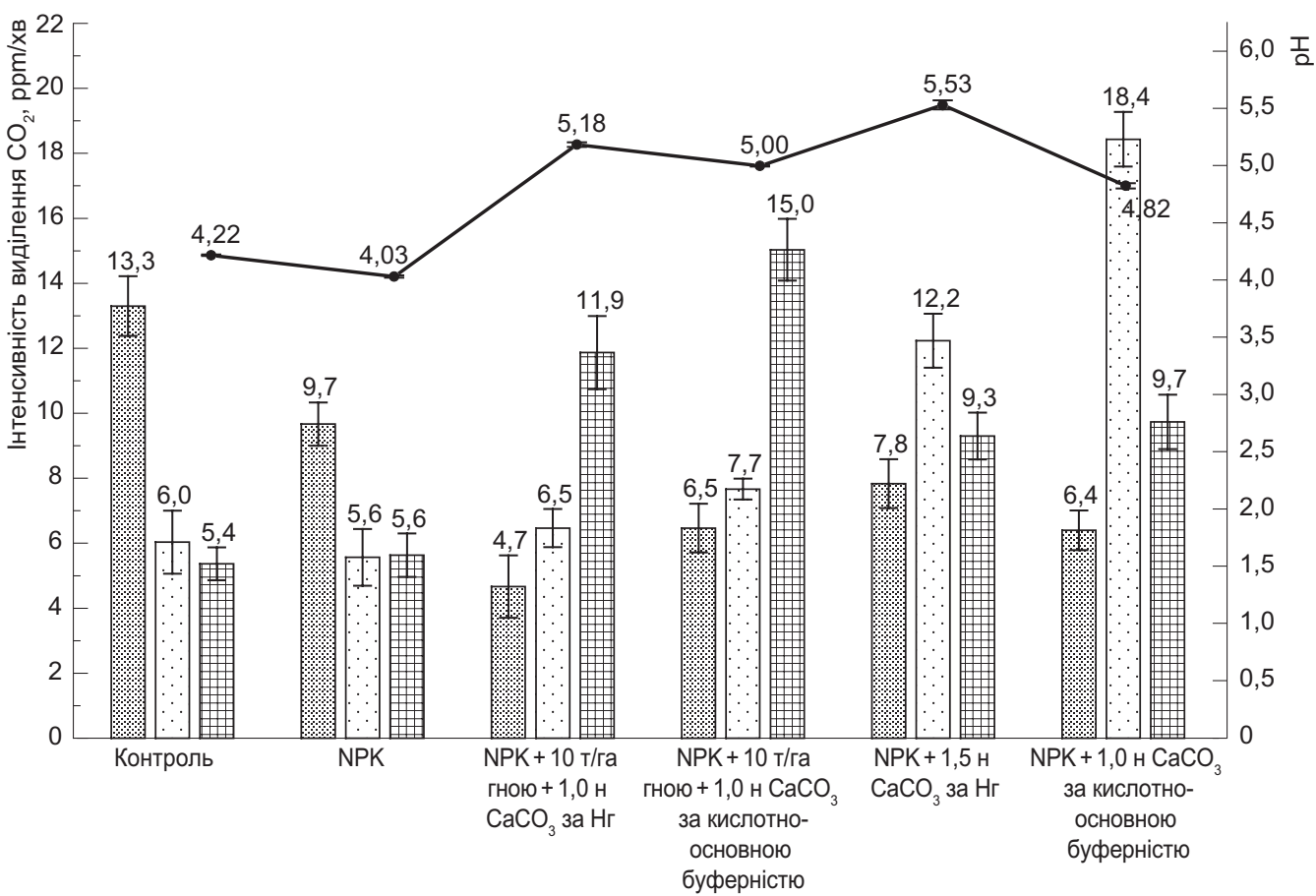

Рис. 1. Динаміка виділення СО під кукурудзою та обмінна кислотність ясно-сірого лісового

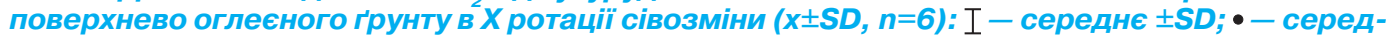

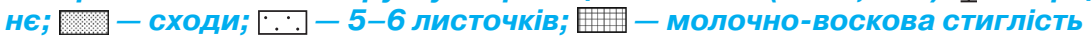


ЗЕМЛЕРОБСТВО, ҐРУНТОЗНАВСТВО, АГРОХІМІЯ
Вплив тривалих антропогенних навантажень на функціональний стан агроекосистем кукурудзи продукування ґрунтом діоксиду вуглецю, особливо в період сходів. Попередні дослідження гумусного стану ясно-сірого лісового поверхнево оглеєного ґрунту показали, що зі зростанням кислотності в гумусі у варіантах контролю та мінерального удобрення підвищується вміст рухомих фульвокислот фракції 1+1«а», здатних до швидкої мінералізації і вимивання в умовах промивного водного режиму [9].

Окисно-відновні реакції в ґрунті проходять досить складно. Крім хімічних процесів, у ґрунті відбуваються окисно-відновні процеси, зумовлені окисненням органічних речовин, що мають незворотний характер.

На характер окисно-відновних процесів і виділення $\mathrm{CO}_{2}$ у ґрунті значною мірою впливають умови аерації. Ї̈̈ погіршення у результаті переущільнення ґрунту чи перезволоження супроводжується зниженням ОВП. Крім того, абсолютні значення Eh не завжди адекватно відображають окисно-відновні умови, оскільки на напруженість окисно-відновних процесів впливає реакція середовища, тому що $є$ тісний зв'язок між $\mathrm{pH}$ і ОВП, про що свідчить показник Кларка [10].
Отримані результати досліджень ОВП свідчать про те, що у фразі сходів під кукурудзою в усіх досліджуваних варіантах переважають процеси окиснення. У варіантах контролю та мінеральної системи удобрення - інтенсивного окиснення. При цьому показники Eh становлять відповідно 641 і 622 мВ. Високі показники 617 і 606 мВ спостерігаються також за органо-мінеральної та мінеральної систем удобрення на фоні вапнування дозою $\mathrm{CaCO}_{3}$ за Нг (рис. 2).

На інтенсивність виділення $\mathrm{CO}_{2}$ і величину ОВП під час сходів у всіх варіантах значний вплив має фактор ранньовесняного обробітку ґрунту і посіву, який, поліпшуючи умови аерації, спричиняє додаткові втрати $\mathrm{CO}_{2}$ та зростання величини Eh через пожвавлення газообміну ґрунту з атмосферою і додаткову мінералізацію рухомих органічних сполук гумусу, особливо у варіантах контролю та мінерального удобрення за низьких значень показника $\mathrm{pH}_{\text {кCl }}$

3 ростом і розвитком рослин показники ОВП знижуються в усіх варіантах до помірно окисних значень. Перед збиранням урожаю вони є найнижчими і становлять від

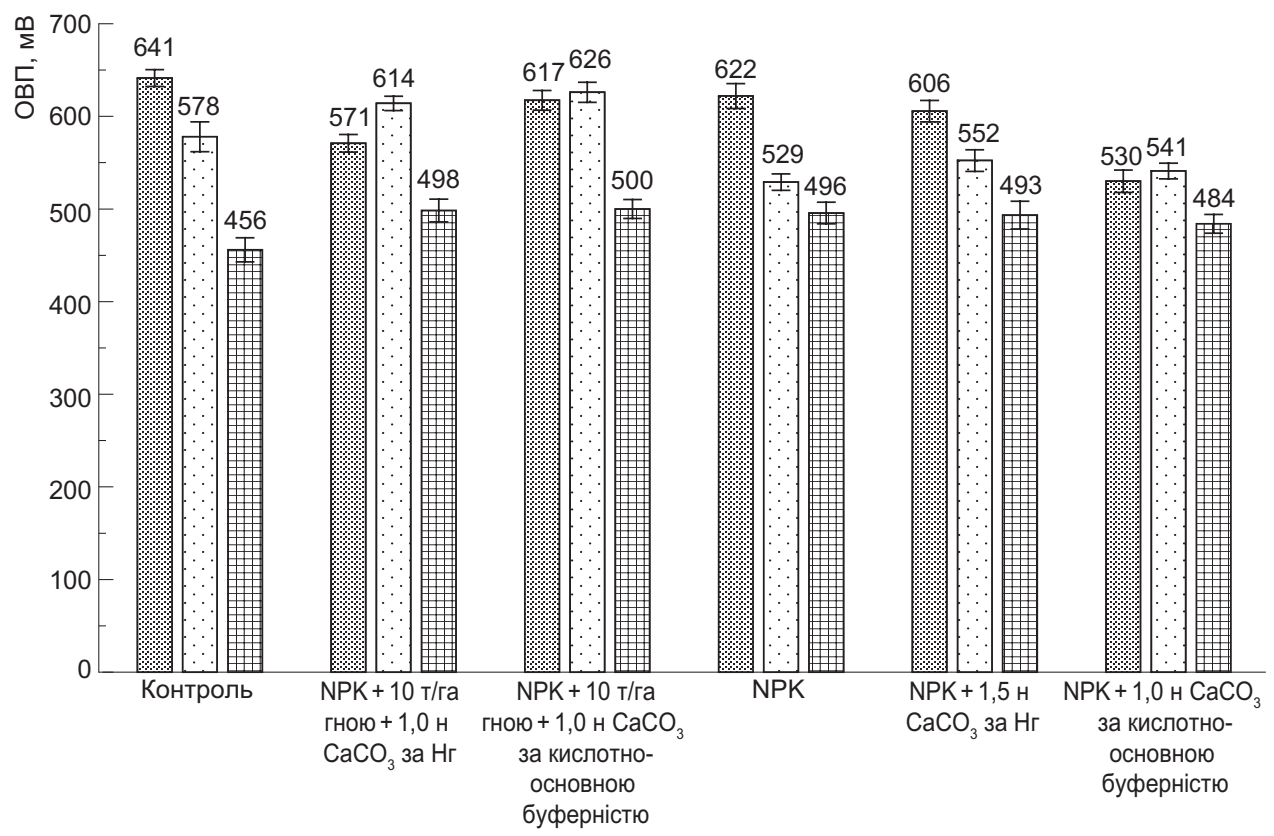

Рис. 2. Динаміка зміни ОВП ясно-сірого лісового поверхнево оглеєного ґрунту під кукуруд-

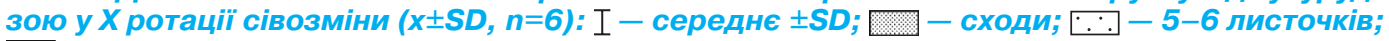
표 - молочно-воскова стиглість 
ЗЕМЛЕРОБСТВО, ҐРУНТОЗНАВСТВО, АГРОХІМІя
Вплив тривалих антропогенних навантажень на функціональний стан агроекосистем кукурудзи
456 мВ на контролі до 500 мВ за органо-мінеральної системи удобрення на фоні вапнування за кислотно-основною буферністю, що відповідає градації слабоокисних.

Оцінюючи отримані показники ОВП та порівнюючи їх із показником Кларка, дійшли висновку, що лише в ґрунті у варіантах мінеральної системи удобрення при $\mathrm{pH}_{\text {ксI }}$ 4,03 та контролю без добрив при $\mathrm{pH}_{\text {ксl }} 4,22$ можливим $€$ прояв у вологі роки відновних процесів і створення відновного середовища.

В умовах ясно-сірих лісових поверхнево оглеєних ґрунтів, як показали дослідження попередніх років, саме у варіантах контролю та мінерального удобрення найбільшою мірою накопичуються аморфні фрорми полуторних оксидів, водорозчинного алюмінію, підвищується рухомість органічних сполук, зростає фульватизація гумусу. Аналогічні результати отримано у модельному досліді В.В. Зубковською [11].

У варіантах поєднаного внесення добрив і вапна порівняно з контролем без добрив і мінеральною системою удобрення ОВП знижується в період активного росту і розвитку рослин на фроні вищої мікробіологічної активності та зростання інтенсивності виділення діоксиду вуглецю.

На напруженість процесів окиснення-відновлення значний вплив має ризосорера рослин і ризосфрерні мікроорганізми. Дослідження мікробного ценозу в умовах стаціонарного досліду на ясно-сірих лісових поверхнево оглеєних ґрунтах показали, що тривале застосування різних систем удобрення на фоні періодичного вапнування мало істотний вплив на функціонування мікроорганізмів у ґрунті (таблиця).

Дослідженнями встановлено, що в полі під кукурудзою, якою розпочинається X ротація сівозміни, найнижчі значення протеазної активності ґрунту, визначеної на основі здатності мікроорганізмів розкладати желатиновий шар рентгенівської плівки, було отримано в контрольному варіанті без добрив $(3,69 \%)$ та варіанті інтенсивного мінерального удобрення (4,13\%). За цих систем удобрення було також отримано й найнижчі значення загальної біологічної активності ґрунту - відповідно 37,54\% і 38,53\%, яку визначали за інтенсивністю розкладання лляного полотна, що за шкалою інтенсивності руйнування целюлози оцінюється як «середня».

Причиною низької біологічної активності ґрунту на контролі без добрив та у варіанті тривалого застосування лише мінеральної системи удобрення $€$ незначна кількість рослинних решток вирощуваних культур. Вони використовуються мікрофлорою як поживний і енергетичний матеріал за високої кислотності ґрунтового розчину ( $\mathrm{pH}_{\text {кс। }}$ становить 4,05-4,22 од., гідролітична кислотність - 4,68-5,03 мг·екв./100 г ґрунту).

У варіантах поєднаного внесення органічних, мінеральних добрив і вапна відзна-

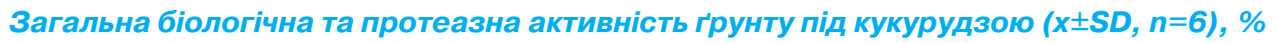

\begin{tabular}{|c|c|c|c|c|}
\hline Варіант & Внесено на 1 га сівозмінної площі & $\begin{array}{l}\text { Удобрення } \\
\text { кукурудзи }\end{array}$ & $\begin{array}{c}\text { Загальна біологічна } \\
\text { активність }\end{array}$ & $\begin{array}{l}\text { Протеазна } \\
\text { активність }\end{array}$ \\
\hline 1 & Без добрив (контроль) & - & $37,54 \pm 1,09$ & $3,69 \pm 0,09$ \\
\hline 7 & $\begin{array}{l}\text { Гній, } 10 \text { т/га }+\mathrm{N}_{65} \mathrm{P}_{68} \mathrm{~K}_{68}+\mathrm{CaCO}_{3} \\
1,0 \text { н за Нг }\end{array}$ & $\begin{array}{l}\text { Гній, } 40 \text { т/га + } \\
+\mathrm{N}_{120} \mathrm{P}_{90} \mathrm{~K}_{90}\end{array}$ & $46,42 \pm 1,21$ & $4,98 \pm 0,12$ \\
\hline 8 & $\begin{array}{l}\text { Гній, } 10 \text { т/га + } \mathrm{N}_{65} \mathrm{P}_{68} \mathrm{~K}_{68}+\mathrm{CaCO}_{3} \\
\text { оптимальна доза за кислотно- } \\
\text { основною буфрерністю }\end{array}$ & $\begin{array}{l}\text { Гній, } 40 \text { т/га + } \\
+\mathrm{N}_{120} \mathrm{P}_{90} \mathrm{~K}_{90}\end{array}$ & $42,40 \pm 1,13$ & $4,64 \pm 0,15$ \\
\hline 15 & $\mathrm{~N}_{65} \mathrm{P}_{68} \mathrm{~K}_{68}$ & $\mathrm{~N}_{120} \mathrm{P}_{90} \mathrm{~K}_{90}$ & $38,53 \pm 1,03$ & $4,13 \pm 0,12$ \\
\hline 17 & $\begin{array}{l}\mathrm{N}_{105} \mathrm{P}_{101} \mathrm{~K}_{101}+\mathrm{CaCO}_{3} \\
1,5 \mathrm{H} \text { за Hr }\end{array}$ & $\mathrm{N}_{180} \mathrm{P}_{135} \mathrm{~K}_{135}$ & $87,32 \pm 1,27$ & $5,27 \pm 0,20$ \\
\hline 18 & $\begin{array}{l}\mathrm{N}_{105} \mathrm{P}_{101} \mathrm{~K}_{101}+\mathrm{CaCO}_{3} \text { оптимальна доза } \\
\text { за кислотно- основною буферністю } \\
\mathrm{HIP}_{05}, \%\end{array}$ & $\mathrm{~N}_{180} \mathrm{P}_{135} \mathrm{~K}_{135}$ & $\begin{array}{c}79,15 \pm 1,19 \\
1,8\end{array}$ & $\begin{array}{c}4,99 \pm 0,17 \\
1,2\end{array}$ \\
\hline
\end{tabular}


ЗЕМЛЕРОБСТВО, ҐРУНТОЗНАВСТВО, АГРОХІМІЯ
Вплив тривалих антропогенних навантажень на функціональний стан агроекосистем кукурудзи чено зростання мікробіологічної активності в період активного росту і розвитку рослин кукурудзи порівняно з контролем без добрив і варіантом мінеральної системи удобрення. Так, застосування органо-мінеральної системи удобрення з унесенням на 1 га сівозмінної площі $\mathrm{N}_{65} \mathrm{P}_{68} \mathrm{~K}_{68}, 10$ т/га гною на фоні внесення вапна за Нг забезпечило загальну біологічну та протеазну активність на рівні відповідно 46,42 і 4,98\%. За цієї системи удобрення, але на фоні внесення оптимальної норми вапна за кислотно-основною буферністю загальна біологічна та протеазна активності становили відповідно 42,4 i 4,64\%.

Унесення високих доз мінеральних добрив на фроні вапнування дозою $\mathrm{CaCO}_{3}$, розрахованою за гідролітичною кислотністю, супроводжувалося значним підвищенням загальної біологічної і протеазної активності відповідно до 87,32 і 5,27\%, що сприятиме не лише поліпшенню умов живлення, а й додатковій мінералізації ґрунту. За аналогічної системи удобрення, але на фоні внесення дози вапна, розрахованої за кислотно-основною буферністю, значення біологічної та протеазної активності були дещо меншими і становили відповідно 79,15 і 4,99\%. Слід зазначити, що за цих систем удобрення за шкалою інтенсивності руйнування целюлози загальна біологічна активність оцінюється відповідно як «дуже сильна» та «сильна».

\section{Висновки}

На основі отриманих результатів досліджень у тривалому стаціонарному досліді показано доцільність використання в системі агроекологічного моніторингу показників емісії $\mathrm{CO}_{2}$, окисно-відновного потенціалу та біологічної активності.
Установлено, що запропоновані діагностичні характеристики разом з агрохімічними показниками дають можливість більш повно та швидко оцінити вплив різних антропогенних навантажень на агроекосистему.
Stasiv O.. ${ }^{1}$ Olifir Yu. ${ }^{2}$, Habryiel A. ${ }^{3}$, Partyka T. ${ }^{4}$, Havryshko O. $^{5}$

Institute of Agriculture of the Carpathian Region of NAAS, 5 Hrushevskoho Str., vil. Obroshyne, Pustomyty district, Lviv oblast, 81115, Ukraine; e-mail: ${ }^{1}$ inagrokarpat@gmail.com, ${ }^{2}$ olifir.yura@ gmail.com, 39abriel.annay@gmail.com, 4, 6tetyana. partyka@gmail.com, ${ }^{5}$ havryshko0@gmail.com; ORCID: ${ }^{1} 0000-0003-3737-739 X,{ }^{2} 0000-0002-7920-$ 1854, ${ }^{3} 0000-0003-4379-3269,{ }^{4} 0000-0001-7912-$ 5292, ${ }^{5} 0000-0002-5458-0691$

\section{Influence of long-term anthropogenic loads on the functional state of corn agroecosystems}

Goal. To study the influence of the long-term application of different fertilizer systems and periodic liming on $\mathrm{CO}_{2}$ emission, the intensity of redox and biotic processes in corn agrocenoses for effective management of fertility of light-gray forest surface gleyed soils. Methods. Field research - to measure the intensity of $\mathrm{CO}_{2}$ emission, the level of redox potential, the proteolytic and general biological activity of the soil, physicochemical - determination of pNKCl, comparative-analytical — to analyze and justify the results, mathematical and statistical - to assess the reliability of research results. Results. With the use of light-gray forest surface-gleyed soils of organo-mineral (10 t/ha of manure and $\mathrm{N}_{65} \mathrm{P}_{68} \mathrm{~K}_{68}$ ) and mineral $\left(\mathrm{N}_{105} \mathrm{P}_{101} \mathrm{~K}_{101}\right)$ fertilizer systems on the background of liming with a dose of $\mathrm{CaCO}_{3}$ calculated on the acid-base buffer (2.5 t/ha), in the 5 th year of the aftereffect, the acidity increases, which leads to an increase in the intensity of $\mathrm{CO}_{2}$ emission, redox potential and a decrease in biotic activity during the growing season of corn. The obtained results testify to the expediency of conducting the next round of liming the light-gray forest surface gleyed soils before the beginning of each of the next 4-field rotations with the optimal dose of $\mathrm{CaCO}_{3}$ calculated on $\mathrm{pH}$-buffering, which will provide a gradual shift of acid-base balance and ecological soils. Conclusions. Based on the obtained research results, a long-term stationary experiment shows the feasibility of using indicators of $\mathrm{CO}_{2}$ emission, redox potential, and biotic activity in the system of agroecological monitoring. It is established that the proposed diagnostic characteristics together with agrochemical indicators make it possible to fully assess the impact of different anthropogenic pressures on the agroecosystem.

Key words: fertilizers, liming, acidity, $\mathrm{CO}_{2}$ emissions, redox potential.

DOI: https://doi.org/10.31073/agrovisnyk202106-02 


\section{Бібліографія}

1. Nahirniak S.V., Dontsova T.A., Lapinsky A.V. et al. Soil and soil breathing remote monitoring: A short review. Biosystems Diversity. 2020. V. 28. №. 4. P. 350-356. doi: 10.15421/012044

2. Цапко Ю.Л., Десятник К.О., Огородня А.І. Меліорація кислих ґрунтів - сучасні погляди і шляхи розвитку. Агрохімія і грунтознавство. 2018. № 87. C. 11-15. doi: 10.31073/ acss87-02

3. Цапко Ю.Л., Десятник К.О., Холодна А.С. та ін. Методологія оперативної діагностики впливу природних та антропогенних навантажень на функціональну стійкість кислих ґрунтів. Харків: Стильна типографія, 2017. 17 с.

4. Балюк С.А., Трускавецький Р.С., Цапко Ю.Л. Хімічна меліорація ґрунтів (концепція інноваційного розвитку). Харків: Міськдрук, 2012. 129 с.

5. Трускавецький Р.С., Цапко Ю.Л. Основи управління родючістю ґрунтів. Харків: ФОП Бровін О.В., 2016. 388 с.

6. Цапко Ю.Л., Десятник К.О., Огородня А.І. Збалансоване використання та меліорація кислих ґрунтів. Харків: ФОП Бровін О.В., 2018. $252 \mathrm{c}$.

7. Pumpanen J., Kolari P., Ilvesniemi $H$. et al. Comparison of different chamber techniques for measuring soil $\mathrm{CO} 2$ efflux. Agricultural and Forest Meteorology. 2004. № 123. P. 159-176. doi: 10.1016/j.agrformet.2003.12.001

8. Федорец Н.Г., Медведева М.В. Методика исследования почв урбанизованных территорий. Петрозаводск: Карельский научный центр РАН, 2009. $84 \mathrm{c}$

9. Снітинський В.В., Габриєль А.Й., Оліфор Ю.М., Германович О.М. Гумусний стан та емісія діоксиду вуглецю в агроекосистемах. Агроекологічний журнал. 2015. № 1. С. 53-58.

10. Мамонтов В.Г., Панов Н.П., Кауричев И.С., Игнатьев Н.Н. Общее почвоведение. Москва: КолосС, 2006. 456 с.

11. Зубковська В.В. Вплив зволоження на поведінку фоссфору у ясно-сірому поверхнево оглеєному лісовому ґрунті. Вісник аграрної науки. 2013. № 8. C. $70-72$. 